Ю.А., Ибрагимов Т.З. Болезни зерновых колосовых культур (рекомендации по проведению фитосанитарного мониторинга). М., 2010.

4. Санин С.С., Неклеса Н.П., Санина А.А., Пахолкова Е.В. Методические рекомендации по созданию инфекционных фонов для иммуногенетических исследований пшеницы / М.: ВНИИФ, 2008. 68 с.

5. Методы оценки и отбора исходного материала при создании сортов пшеницы устойчивых к бурой ржавчине. / Методические рекомендации под редакцией академика Санина С.С. М.: 2012. 93 с.

6. Изучение генетических ресурсов зерновых культур по устойчивости к вредным организмам / Методическое пособие под редакцией Радченко Е.Е. М.: Россельхозакадемия, 2008. 418 с.

DOI 10.18699/GPB2020-14

\title{
Crop genebanks - the maintenance of natural resources for future plant breeding
}

Börner A. *, Nagel M., Lohwasser U.

Leibniz Institute of Plant Genetics and Crop Plant Research (IPK), Gatersleben, Germany.

*e-mail: boerner@ipk-gatersleben.de

Plant genetic resources for food and agriculture (PGRFA) play a major role for global food security. The most significant and widespread mean of conserving PGRFA is ex situ conservation. Most conserved accessions are kept in specialized facilities known as genebanks maintained by public or private institutions. Worldwide 7.4 million accessions are stored in about 1,750 ex situ genebanks.

Plant ex situ genebank collections comprise seed genebanks, field genebanks as well as in vitro and cryo collections. Species whose seed can be dried, without damage, down to low moisture contents can be conserved in specially designed cold stores. Such "orthodox" seeds can be expected to maintain a high level of vigour and viability for decades. Field genebanks, in vitro and cryo storage are used primarily for species which are either vegetatively propagated or which have non-orthodox seeds that cannot be dried and stored for long periods. In addition, perennial species, for example certain forage species, which produce small quantities of seed, and long-lived plants are also maintained this way. It is estimated that worldwide, less than $10 \%$ of genebank holdings are stored in vivo in the field, and less than $1 \%$ are conserved in vitro/cryo. Clearly, seed storage is the predominant mode of plant genetic resources conservation.

With a total inventory of 150,000 accessions from 3,212 plant species and 776 genera, the 'Federal ex situ Genebank of Germany' in Gatersleben holds one of the most comprehensive collections worldwide. It comprises wild and primitive forms, landraces as well as old and more recent cultivars of mainly cereals but also 
other crops. Starting in the 1920's material was accumulated systematically. Seed storage is managed in large cold chambers at $-18^{\circ} \mathrm{C}$. Seeds are kept in glass jars, covered with bags containing silica gel (active collection) and in aluminum bags under vacuum (base collection).

The maintenance of the collection requires regeneration. Each year between 8 and $10 \%$ of the collection is grown either in the field or in glasshouses. Regeneration becomes necessary when: (1) the quantity of stored seed has dropped below a pre-set threshold, due to supply to users, (2) viability falls below a pre-set threshold, (3) phenotypic evaluations of the accessions need to be conducted or (4) new accessions, which require multiplication and characterization, enter the collection. Regeneration is carried out locally to ensure genetic integrity and to minimize genetic erosion. Voucher specimens, photographs and written documentation are used to monitor the identity of the material. Special attention has to be given to out-pollinating species, which are either multiplied in small glasshouses or in isolation plots in the field.

Since the majority of genebank accessions globally are stored in the form of seed, seed longevity is of particular importance for crop germplasm preservation. At the IPK research was initiated for a range of crops stored in the genebank over decades. Variation between and within crop species was detected.

DOI $10.18699 / \mathrm{GPB} 2020-15$

\section{Генетические механизмы ответа растений на световой стресс: реконструкция генных сетей и эволюционная перспектива}

Бобровских А.В. ${ }^{1}$, м.н.с.; Ермаков А.А. ${ }^{l}$, м.н.с.; Зубаирова У.С. ${ }^{1}$, к.б.н., н.с.; Константинов Д.К. ${ }^{l}$, м.н.с.; Левина А.Б. ${ }^{2}$, студентка; Колодкин А.Н. ${ }^{3,4,5}$, проф.; Хейдари С. ${ }^{6}$; Дорошков А.В. ${ }^{1 *}$, к.б.н., н.с.

${ }^{1}$ ИЦиГ СО РАН, Новосибирск, Россия;

${ }^{2}$ НГУ, Новосибирск, Россия;

${ }^{3}$ Свободный Университет Амстердама, Амстердам, Нидерланды;

${ }^{4}$ Университет Амстердама, Амстердам, Нидерландь;

${ }^{5}$ Люксембургский Центр Системной Биомедицины, Университет Люксембурга, Люксембург;

${ }^{6}$ Мешхедский университет им. Фердовси, Мешхед, Иран.

*e-mail:ad@bionet.nsc.ru

Растения преобразуют энергию солнща в энергию химических связей и поэтому являются фундаментом экосистем и промышленности. Понимание того, как растения контролируют наработку биомассы, как преобразуют энергию солниа и как используют ее для создания органов и тканей 